\title{
PERUBAHAN STRATEGI OPERASI PENANGKAPAN IKAN NELAYAN KARIMUNJAWA, JAWA TENGAH
}

\section{(STRATEGY OPERATING FISHERMAN FISHING IN KARIMUNJAWA, CENTRAL JAVA)}

\author{
Eko Sri Wiyono ${ }^{1,2}$ dan ${ }^{3}$ Tasrif Kartawijaya \\ ${ }^{1}$ Corresponding author \\ ${ }^{2}$ Departemen Pemanfaatan Sumberdaya Perikanan, Fakultas Perikanan dan Ilmu Kelautan IPB \\ Jl. Lingkar Akademik Kampus IPB, Darmaga Bogor, E-mail: eko_ipb@yahoo.com \\ ${ }^{3}$ Wildlife Conservation Society - Indonesia Program \\ Jl. Burangrang No.18, Bogor, E-mail: tkartawijaya@wcs.org
}

\begin{abstract}
Reef fishery is one of the main activities of fishermen in the tropic area. Changing of economy and ecology has resulted in changes in revenue and operating strategies of fishing. Fishermen have used a variety of strategies to maintain their activity. To examine this problem, we conducted the reseach in Karimunjawa, Central Java. The results of this study suggest that fish composition, fishing gear productivity and fishing gear which used by fishermen bave changed over the period $2003-2005$ and from 2009 to 2011. When during period of 2003 - 2005 fising trip of gear was dominated by muroami, then in the period 2009 - 2011 fishing trip dominated by speargun (arrows). These changes, thought to be caused by changes in market demand especially yellow tail (Caesio sp), the fishing operations cost and catches both in number and composition of fish.
\end{abstract}

Keywords: Yellow tail (Caesio sp.), Karimunjawa, catch composition, speargun, muroami.

\begin{abstract}
ABSTRAK
Perikanan karang merupakan salah satu pusat kegiatan penangkapan ikan nelayan kecil di daerah tropis. Seiring dengan perubahan ekonomi dan ekologi, telah mengakibatkan berubahnya pendapatan dan strategi operasi penangkapan ikan. Nelayan telah menggunakan berbagai macam strategi untuk mempertahankan usahanya. Untuk mengkaji hal tersebut, telah dilakukan penelitian di Karimunjawa. Hasil penelitian ini menyebutkan bahwa komposisi ikan hasil tangkapan, produktivitas alat tangkap dan alat tangkap yang digunakan oleh nelayan telah mengalami perubahan dalam periode 2003 - 2005 dan 2009 - 2011. Bila pada periode 2003 - 2005 operasi penangkapan ikan didominasi oleh muroami, maka pada periode 2009 2011 trip penangkapan ikan didominasi oleh speargun (panah). Perubahan tersebut, diduga disebabkan oleh berubahnya permintaan pasar khususnya ekor kuning (Caesio sp), biaya operasi penangkapan dan hasil tangkapan baik dalam jumlah maupun komposisi ikan.
\end{abstract}

Kata kunci: Gillnet, hauling, lama trip penangkapan, Pekalongan

\section{PENDAhUluan}

Hampir 90\% perikanan Indonesia didominasi oleh perikanan skala kecil. Umumnya, mereka mengoperasikan alat tangkapnya di pesisisr pada ekosistem estuari. Salah satu ekosistem yang menjadi target penangkapan ikan adalah terumbu karang. Seperti disampaikan oleh Cesar et al., (1997) dan Campbell \& Pardede (2006), kegiatan perikanan skala kecil pada ekosistem terumbu karang merupakan sumber pendapatan dan makanan yang penting bagi masyarakat pesisir di Indonesia. Perikanan terumbu karang yang dicirikan oleh tingginya produktivitas dan tingkat keberagaman sumberdaya, dewasa ini telah mengalami tekanan yang demikian hebat. Beberapa species ikan telah punah dan hasil tangkapan ikan semakin menurun. Ardiwijaya et al. (2008) menjelaskan akan terjadi penurunan biomasa ikan karang pada periode tahun 2007 dibandingkan tahun 2005 dan 2006 masing-masing sebesar $60 \%$ dan $57 \%$ terutama pada kelompok tropik ikan karnivora (Famili Lutjanidae, Nempteridae, Serranidae, Lethrinidae), herbivora (Famili Scaridae, Siganidae, Pomacanthidae, Kyphosidae, Acanthuridae) dan planktivora (Famili Caesionidae).

Disisi lainnya, jumlah nelayan miskin yang menggantungkan kehidupannya dari perikanan pantai mengalami peningkatan. Akibatnya, 
konflik pemanfaatan dan degradasi sumberdaya ikan di daerah pantai semakin meningkat dan tidak bisa terhindarkan. Sejak mekanisasi, modernisasi dan penggunaan inputan dari pabrik menggantikan alat dan bahan tradisional, perikanan skala kecil menunjukkan tren peningkatan dalam jumlah dari tahun ke tahun dan menimbulkan persoalan yang berkaitan dengan overcapacity dan pengurangan kelebihan jumlah upaya penangkapan (Berkes et.al., 2001). Peningkatan tipe, jumlah, ukuran dan efisiensi alat tangkap pada perikanan skala kecil pantai yang bersifat multispeciesmultigear di negara berkembang ditengarai telah meningkatkan tekanan penangkapan terhadap ketersediaan stok ikan. Sebagai akibatnya, penurunan ketersediaan ikan dan kualitas ekologi di beberapa daerah tidak dapat dihindari (Berkes et al., 2001).

Meskipun berbagai penelitian telah dilakukan untuk memperbaiki kondisi yang ada, ternyata kondisi perikanan di negara ketiga belum juga membaik. Selama ini, pengelolaan perikanan hanya difokuskan pada aspek biologi semata. Selain kesehatan biodiversitas dan ekosistem, ada aspek utama lainnya yang juga harus dipahami dengan benar, yaitu tingkah laku manusia dalam memanfaatkan sumberdaya laut. Hal ini karena dalam menghadapi keterbatasannya, nelayan akan mengembangkan dan menerapkan strategi penangkapan ikan tertentu dalam mengalokasikan alat tangkapnya (Salas \& Gaertner, 2004).

Untuk memahami bagaimana nelayan skala kecil melakukan strategi operasi penangkapannya, telah dilakukan penelitian di perairan Karimunjawa. Wibowo (2005) menyatakan bahwa sebagian besar (61\%) masyarakat Karimunjawa yang berusia produktif berprofesi sebagai nelayan yang menggantungkan hidupnya pada sumberdaya perikanan khususnya perikanan karang. Tujuan penelitian ini adalah mengkaji perubahan strategi operasi penangkapan ikan nelayan Karimunjawa. Secara rinci penelitian ini bertujuan untuk:
1) Mengkaji perubahan hasil tangkapan dan upaya penangkapan ikan karang di Taman Nasional Karimunjawa.

2) Mengkaji strategi operasi penangkapan ikan nelayan di Taman Nasional Karimunjawa.

\section{METODOLOGI PENELITIAN}

\subsection{Pengambilan data}

Penelitian ini dilaksanakan di Taman Nasional Karimunjawa, Kabupaten Jepara, Jawa Tengah (Gambar 1). Pengambilan data dilakukan pada bulan Januari - Desember pada tahun 2005, 2006, 2007, 2009, 2010 dan 2011. Data hasil tangkapan nelayan dikumpulkan dari perahu yang mendaratkan ikan hasil tangkapannya di desa Karimunjawa. Pemilihan desa Karimunjawa sebagai lokasi pengambilan sampel didasarkan atas informasi bahwa lebih dari $50 \%$ hasil tangkapan ikan di Kepulauan Karimunjawa didaratakan di Desa Karimunjawa dan alat tangkap yang digunakan paling bervariasi dibandingkan lokasi lainnya (Mukminin et al. 2006). Data dikumpulkan dari aktivitas 50 nelayan yang terpilih selama 15 hari setiap bulannya sepanjang tahun 2005, 2006, 2007, 2009, 2010 dan 2011. Penentuan responden dilakukan dengan metode purposive sampling. Target responden dalam penelitian ini adalah nelayan Kepulauan Karimunjawa yang telah melaut selama 5 tahun atau lebih. Pengumpulan data dilakukan melalui wawancara mendalam dan diskusi terarah secara individu disertai pengisian kuisioner.

Trip operasi penangkapan ikan bulanan diperoleh dengan menjumlahkan jumlah trip operasi penangkapan ikan dari masing-masing nelayan pada setiap bulannya. Seperti trip operasi penangkapan ikan, data lainnya yang meliputi jumlah hasil tangkapan (kg), jenis ikan, famili, lokasi penangkapan ikan, jenis alat tangkap, biaya operasional (Rp./trip) dan harga ikan (Rp./kilogram) juga diakumulasikan dari masing-masing responden sehingga diperoleh data bulanan. 




Gambar 1 Peta lokasi penelitian di Taman

\subsection{Analisis data}

Secara umum, analisis data yang digunakan dalam kajian ini adalah analisis deskriptif. Informasi tentang perubahan alat tangkap, hasil tangkapan dan pendapatan alat tangkap yang dioperasikan oleh nelayan diperbandingkan antar alat tangkap dan tahun dengan menggunakan tabel dan grafik. Respon nelayan dalam operasi penangkapan ikan terhadap perubahan luar yang terjadi dianalisis dengan membandingkan jumlah trip alat tangkap antar waktu dan perubahan alat tangkap yang digunakan. Cinner et al. 2008 menyebutkan bahwa respon nelayan terhadap perubahan luar adalah dengan cara lebih sering melaut, mengurangi frekuensi melaut, pindah lokasi penangkapan dan ganti alat tangkap. Sementara faktor penyebab perubahan pola operasi dalam hal ini adalah hasil tangkapan dan pendapatan dianalisis secara deskriptif juga dengan memperbandingkan antar alat tangkap dan waktu (tahun).

\section{HASIL DAN PEMBAHASAN}

\subsection{Hasil}

\subsubsection{Perubahan hasil tangkapan}

Data hasil tangkapan masingmasing alat tangkap sampel menunjukkan bahwa total hasil tangkapan alat tangkap gillnet dan muroami mempunyai kecenderungan menurun. Sementara hasil tangkapan handline, speargun dan trap (bubu) menunjukkan kecenderungan meningkat. Hasil tangkapan muroami yang selama ini mendominasi hasil tangkapan di Karimunjawa mulai menurun dan tergantikan oleh alat tangkap yang lain seperti speargun.

Berdasarkan Gambar 2 dapat diketahui bahwa, jika pada periode 2003 - 2005 hasil tangkapan muroami bisa mencapai $30.529 \mathrm{~kg}$ (tahun 2003), tetapi pada periode 2009 - 2011 hanya mencapai maksimum $15.469 \mathrm{~kg}$ (tahun 2010). Sebaliknya untuk alat tangkap muroami bila pada periode 2003 - 2005 maksimum hanya mencapsi $153 \mathrm{~kg}$ (tahun 2003) pada periode $2009-2011$ bisa mencapai $27.028 \mathrm{~kg}$ (tahun 2010). 
Perubahan hasil tangkapan dari masing-masing alat tangkap tersebut berkaitan dengan perubahan target penangkapan ikan nelayan di Karimunjawa (Tabel 1). Dalam penelitian ini, jumlah spesies yang ditemukan adalah sebanyak 377 spesies dari 61 famili. Bila pada periode tahun 2003 - 2005 hasil tangkapan didominasi hasil tangkapan lain-lain $(38,86 \%$ $53,80 \%$ ) maka pada periode $2009-2011$ hasil tangkapan didominasi oleh famili Caesionidae $\quad(51,66 \% \quad$ - $60,19 \%)$. Perubahan itu, diduga karena berkembangnya perikanan ekor kuning yang sangat pesat, sehingga orientasi penangkapan nelayan adalah menangkap ikan ekor kuning. Disamping ekor kuning, ikan yang cukup mendominasi hasil tangkapan ikan yang didaratkan di Karimunjawa adalah Scombridae (12,18\% - 23,50\%).

\subsubsection{Perubahan produktivitas alat penangkapan ikan \\ Bila ditinjau dari produktivitas} alat penangkapan ikan, secara umum semua alat tangkap menunjukkan kecenderungan peningkatan produktivitas. Meskipun menunjukkan kecenderungan hasil tangkapan yang menurun, produktivitas muroami dan gillnet masih meningkat (Gambar 3). Kecenderungan yang sama juga terjadi pada alat tangkap speargun, handline (pancing ulur) dan trap (bubu).

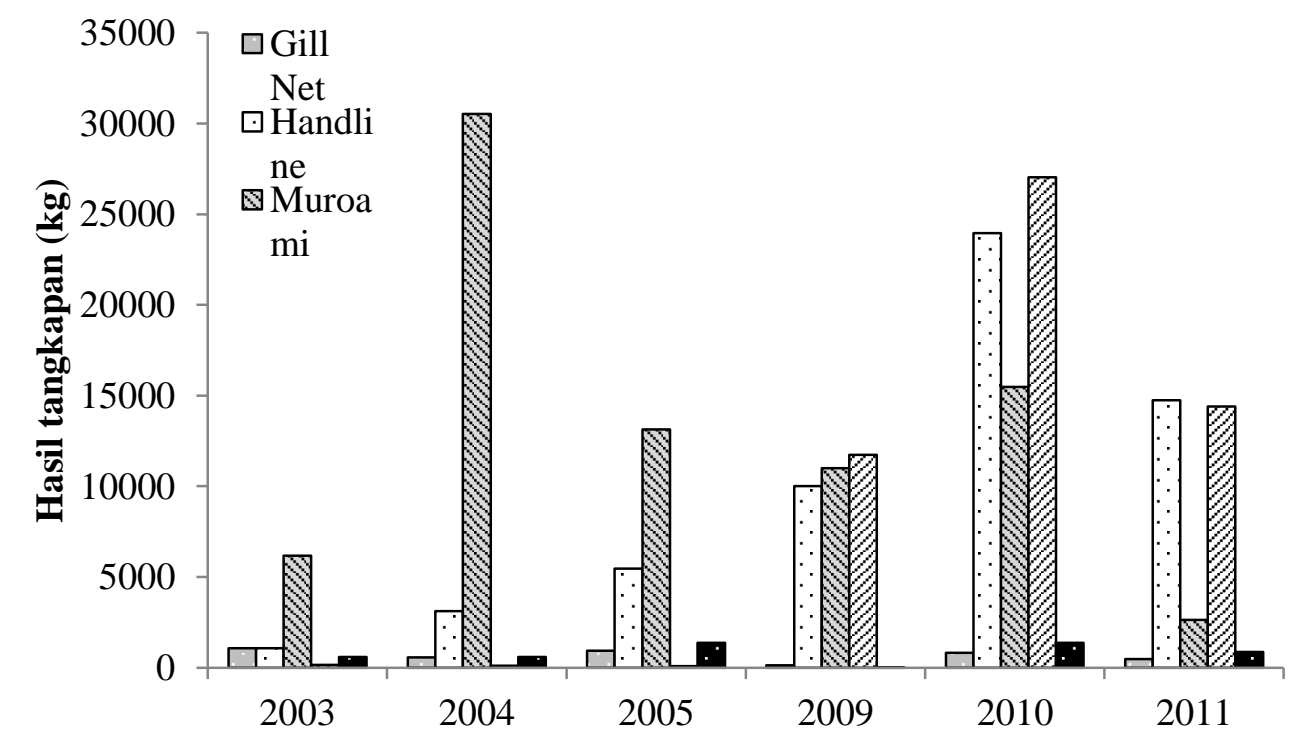

Gambar 2. Total hasil tangkapan (kg) setiap alat tangkap pada periode $2003-2005$ dan $2009-2011$

Tabel 1. Komposisi hasil tangkapan (\%) setiap famili pada pariode pengamatan 2003 hingga 2005 dan periode 2009 dan 2011

\begin{tabular}{llllllll}
\hline \multirow{2}{*}{ No } & \multirow{2}{*}{ Family } & \multicolumn{7}{l}{ Komposisi hasil tangkapan (\%) } \\
\cline { 3 - 8 } & 2003 & 2004 & 2005 & 2009 & 2010 & 2011 \\
\hline 1 & Caesionidae & 14.13 & 8.80 & 16.08 & 60.19 & 54.20 & 51.61 \\
2 & Scombridae & 1.92 & 2.52 & 4.81 & 20.62 & 12.18 & 23.50 \\
3 & Carangidae & 9.24 & 6.32 & 6.72 & 3.36 & 14.21 & 6.96 \\
4 & Scaridae & 8.00 & 8.88 & 10.30 & 3.13 & 3.66 & 2.19 \\
5 & Serranidae & 7.26 & 4.40 & 5.10 & 6.27 & 6.52 & 5.83 \\
6 & Lutjanidae & 5.78 & 5.04 & 3.18 & 1.94 & 3.67 & 6.32 \\
7 & Acanthuridae & 6.86 & 5.54 & 8.31 & 0.25 & 0.27 & 0.05 \\
8 & Siganidae & 7.95 & 4.69 & 5.05 & 0.07 & 0.64 & 0.28 \\
9 & Lainnya & 38.86 & 53.80 & 40.45 & 4.15 & 4.64 & 3.26 \\
\hline
\end{tabular}


Ketiga alat tangkap tersebut menunjukkan kecenderungan peningkatan produktivitas. Meningkatnya teknologi dan pengetahuan nelayan, diduga menjadi faktor pendorong terhadap peningkatan produktivitas alat tangkap.

\subsubsection{Perubahan upaya penangkapan ikan}

Upaya penangkapan ikan pada periode 2003 - 2005 kecuali alat tangkap muroami menunjukkan kecenderungan meningkat (Gambar 4). Perubahan upaya paling menonjol ditunjukkan oleh speargun dan handline. Bila jumlah handline (pancing ulur) pada tahun 2003 sebanyak 152 meningkat menjadi 781 pada tahun 2011 bahkan pada tahun 2010 mencapai 1120 trip. Demikian juga speargun, bila pada tahun 2003 ada 16 trip penangkapan maka pada tahun
2011 mencapai 221 trip bahkan pada tahun 2010 mencapai 436 trip. Kondisi sangat bertolak belakang dengan alat tangkap muroami, gillnet dan trap (bubu). Moroami mengalami penurunan dari 47 trip (2003) menjadi 5 trip (2011), sedangkan trap (bubu) (52 trip) dan gillnet (38 trip) pada tahun 2003 mengalami penurunan menjadi 26 trip dan 8 trip pada tahun 2011 .

Pada periode 2003 - 2005 upaya penangkapan ikan didominasi oleh handline (pancing ulur) (54,4\%), muroami $(18,2 \%)$ dan trap (bubu) (15,4\%). Tetapi pada periode 2009 2011, alat tangkap gillnet, muroami dan trap (bubu) menunjukkan kecenderungan menurun. Sebaliknya, alat tangkap handline (pancing ulur) $(70,8 \%)$ dan speargun $(24,0 \%)$ mengalami peningkatan jumlah dan mendominasi alat tangkap yang ada (Tabel 2).

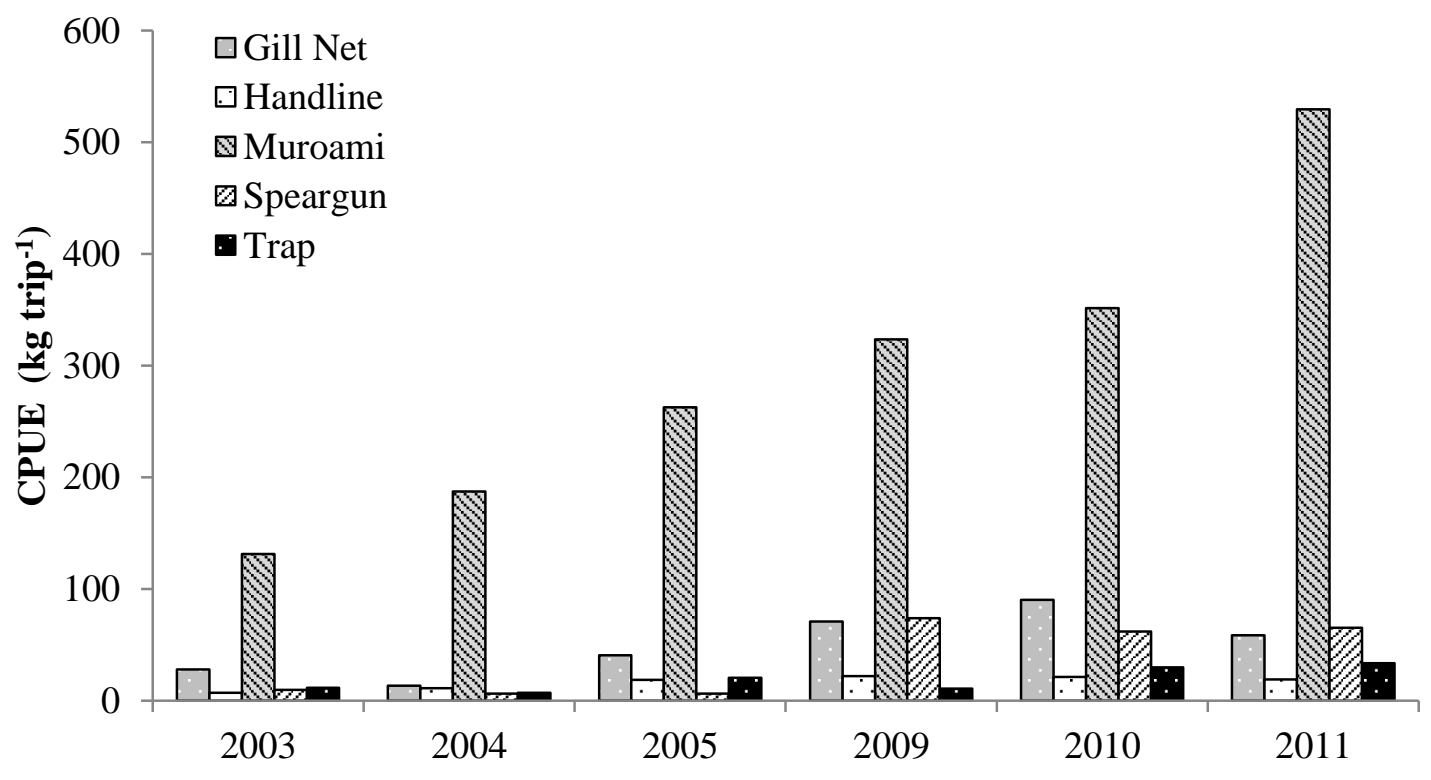

Gambar 3. Hasil tangkapan per upaya tangkap (kg trip $\left.{ }^{-1}\right)$ setiap alat tangkap pada setiap peride pengamatan 


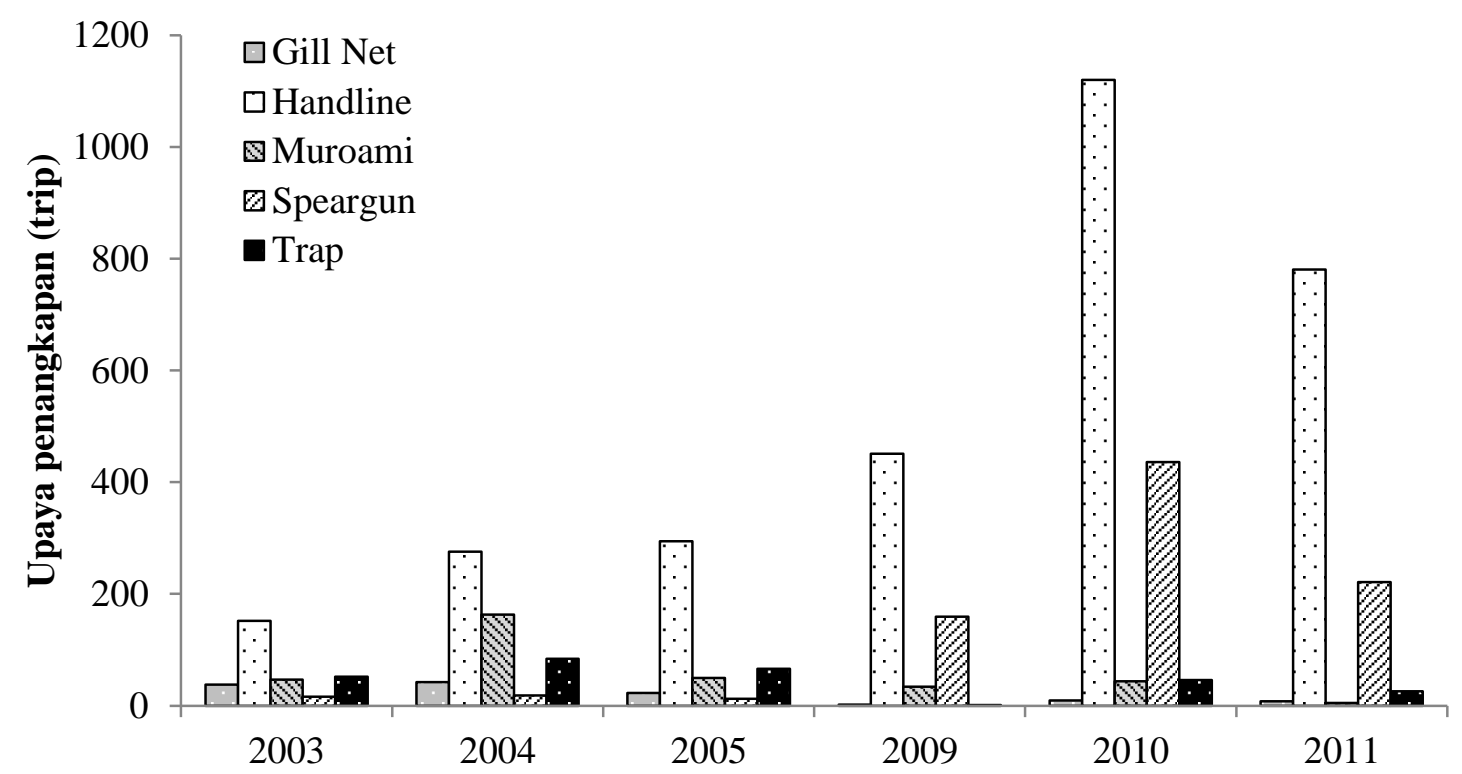

Gambar 4. Perubahan trip penangkapan alat penangkapan ikan periode $2003-2005$ dan periode $2009-2011$

\subsubsection{Biaya operasional dan pen- dapatan}

Faktor pembatas yang sering menjadi kendala dan merupakan faktor penentu dalam kegiatan operasi penangkapan ikan adalah biaya dan pendapatan usaha. Dalam kajian ini, biaya dan pendapatan usaha dikaji pada periode 2009 - 2011, karena data pada tahun sebelumnya belum tersedia. Biaya rata-rata operasi penangkapan ikan gillnet dari tahun 2009 - 2011 secara umum menunjukkan peningkatan, sementara pendapatan juga menunjukkan peningkatan. Namun demikian, keuntungan rata-rata gillnet dari tahun 2010 - 2011 menunjukkan kecenderungan menurun.

Demikian juga rasio pendatan dan biaya juga menunjukkan kecenderungan menurun (Tabel 3).
Kondisi yang hampir sama terjadi pada muroami, handline (pancing ulur) dan trap (bubu), biaya operasi penangkapan dan pendapatannya meningkat.

$$
\text { Meskipun keuntungannnya }
$$

meningkat tetapi rasio pendapatan dan biaya operasi penangkapannya menurun. Kondisi yang berbeda terjadi pada speargun, biaya operasi penangkapan ikan secara umum tidak mengalami perubahan demikian juga pendapatan dan keuntungannya. Demikian juga dengan rasio pendapatan dan biaya operasi penangkapan ikan tidak mengalami perubahan yang drastis. Secara umum alat tangkap speargun mempunyai performa usaha yang relatif stabil dalam tiga tahun terakhir. 
Tabel 2. Komposisi upaya penangkapan (\%) setiap alat tangkap pada setiap periode pengamatan

\begin{tabular}{llllll}
\hline \multirow{2}{*}{ Tahun } & \multicolumn{5}{l}{ Komposisi upaya penangkapan $(\%)$} \\
\cline { 2 - 6 } & Gillnet & Handline & Muroami & Speargun & $\begin{array}{l}\text { Trap } \\
\text { (bubu) }\end{array}$ \\
\hline 2003 & 12.46 & 49.84 & 15.41 & 5.25 & 17.05 \\
2004 & 7.20 & 47.34 & 27.96 & 3.09 & 14.41 \\
2005 & 5.17 & 66.07 & 11.24 & 2.70 & 14.83 \\
2009 & 0.31 & 69.71 & 5.26 & 24.57 & 0.15 \\
2010 & 0.54 & 67.67 & 2.66 & 26.34 & 2.78 \\
2011 & 0.77 & 75.02 & 0.48 & 21.23 & 2.50 \\
\hline
\end{tabular}

Tabel 3. Keragaan usaha penangkapan ikan di Karimunjawa pada periode 2009 2011

\begin{tabular}{|c|c|c|c|c|c|c|c|c|c|c|c|c|c|}
\hline \multirow[b]{2}{*}{ Tahun } & \multirow[b]{2}{*}{$\begin{array}{l}\text { Alat } \\
\text { Tangkap }\end{array}$} & \multicolumn{3}{|c|}{ Biaya operasinal per trip (Rp) } & \multicolumn{3}{|c|}{ Pendapatan per trip (Rp) } & \multicolumn{3}{|c|}{ Keuntungan/trip (Rp) } & \multicolumn{3}{|c|}{ Pendapatan/biaya } \\
\hline & & Min & Max & $\begin{array}{l}\text { Rata- } \\
\text { rata }\end{array}$ & Min & Max & Rata-rata & Min & $\operatorname{Max}$ & Rata-rata & Min & $\operatorname{Max}$ & $\begin{array}{l}\text { Rata- } \\
\text { rata }\end{array}$ \\
\hline 2009 & Gillnet & $\mathrm{n} / \mathrm{a}$ & $\mathrm{n} / \mathrm{a}$ & $\mathrm{n} / \mathrm{a}$ & 65.000 & 592.000 & 328.500 & & & & & & \\
\hline 2010 & Gillnet & 50.000 & 300.000 & 216.667 & 87.000 & 2.033 .800 & 687.589 & 37.000 & 1.733 .800 & 470.922 & 1,74 & 6,78 & 3,17 \\
\hline 2011 & Gillnet & 10.000 & 500.000 & 252.500 & 115.000 & 1.322 .500 & 624.750 & 105.000 & 822.500 & 372.250 & 11,50 & 2,65 & 2,47 \\
\hline 2009 & Handline & 90.000 & 110.000 & 96.286 & 5.500 & 4.303 .200 & 311.728 & -84.500 & 4.193 .200 & 215.442 & 0,06 & 39,12 & 3,24 \\
\hline 2010 & Handline & 10.000 & 300.000 & 98.166 & 2.000 & 4.041 .500 & 332.479 & -8.000 & 3.741 .500 & 234.313 & 0,20 & 13,47 & 3,39 \\
\hline 2011 & Handline & 10.000 & 450.000 & 96.388 & 6.000 & 2.957 .000 & 257.784 & -4.000 & 2.507 .000 & 161.396 & 0,60 & 6,57 & 2,67 \\
\hline 2009 & Muroami & $\overline{\mathrm{n}}$ & $\mathrm{n} / \mathrm{a}$ & $\mathrm{n} / \mathrm{a}$ & 14.000 & 9.370 .000 & 3.279 .046 & & & & & & \\
\hline 2010 & Muroami & 400.000 & 550.000 & 449.231 & 17.208 & 11.600 .000 & 3.187 .695 & 382.792 & 11.050 .000 & 2.738 .464 & 0,04 & 21,09 & 7,10 \\
\hline 2009 & Speargun & 275.000 & 300.000 & 285.714 & $\mathrm{n} / \mathrm{a}$ & 3.286 .000 & 961.892 & & 2.986 .000 & 676.178 & & 10,95 & 3,37 \\
\hline 2010 & Speargun & 30.000 & 350.000 & 258.483 & 19.500 & 8.889 .100 & 950.862 & -10.500 & 8.539 .100 & 692.379 & 0,65 & 25,40 & 3,68 \\
\hline 2011 & Speargun & 50.000 & 320.000 & 273.351 & 14.400 & 2.501 .000 & 792.006 & -35.600 & 2.181 .000 & 518.655 & 0,29 & 7,82 & 2,90 \\
\hline 2009 & $\begin{array}{l}\text { Trap } \\
\text { (bubu) }\end{array}$ & 5.000 & 5.000 & 5.000 & 143.000 & 143.000 & 143.000 & 138.000 & 138.000 & 138.000 & 28,60 & 28,60 & 28,60 \\
\hline 2010 & (bubu) & 5.000 & 200.000 & 107.581 & 5.000 & 3.214 .600 & 502.410 & 0 & 3.014 .600 & 394.829 & 1,00 & 16,07 & 4,67 \\
\hline 2011 & $\begin{array}{l}\text { Trap } \\
\text { (bubu) }\end{array}$ & 5000 & 160000 & 111889 & 13600 & 1751300 & 634741 & 8600 & 1591300 & 522852 & 2,72 & 10,95 & 5,67 \\
\hline
\end{tabular}

\subsection{Pembahasan}

Ricker (1975) \& Hazin et al., (2007) mengungkapkan bahwa strategi operasi penangkapan ikan akan berubah setiap waktu. Beberapa faktor yang dipertimbangkan oleh nelayan untuk mengganti strategi operasi penangkapannya adalah pasar, tujuan pengolahan, teknologi penangkapan yang digunakan dan yang paling utama adalah stok ikan. Hasil dari penelitian ini menyebutkan bahwa terjadi perubahan komposisi alat penangkapam ikan di Karimunjawa. Alat tangkap muroami yang dulunya menjadi alat tangkap utama telah digeser oleh alat tangkap lain khususnya speargun.

Perubahan ekosistem dan ekonomi di lingkungan nelayan diduga telah menjadi pendorong perubahan yang terjadi. Minimnya aksesibilitas transportasi laut yang menghubungkan nelayan Karimunjawa dengan daratan utama (Kota Jepara dan Kota Semarang) serta terbatasnya alternatif pekerjaan masyarakat Karimunjawa menyebabkan sebagian besar masyarakat menggantungkan hidupnya pada sumberdaya perikanan dan tetap tinggal di daerahnya dengan konsekuensi harus melakukan perubahan strategi penangkapan ikan jika sumberdaya ikan dan lingkungan mengalami perubahan. Setiap perubahan lingkungan yang terjadi dan mempengaruhi sumberdaya ikan yang mereka tangkap, akan mereka respon dengan pola-pola adaptasi yang mereka kembangkan. Cinner et al. (2008) menyatakan bahwa ketika nelayan dihadapkan dengan skenario hasil tangkapan yang menurun, maka nelayan akan berhenti menangkap ikan, mencari alternatif seperti pindah lokasi tangkap atau mengganti alat tangkap dan akan lebih intensif menangkap ikan. Selanjutnya McClanahan \& Mangi (2000) menjelaskan bahwa biasanya nelayan akan beradaptasi dengan menambah alat tangkap di lokasi penangkapan mereka dan tidak menyebar di area yang lebih luas. 
Dalam kasus nelayan di Karimunjawa ini, nelayan telah melakukan perubahaan strategi operasi penangkapannya dengan mengganti alat tangkap muroami dengan alat tangkap yang lain khususnya speargun (panah). Berubahnya permintaan pasar dalam mengkonsumsi ikan khusus terhadap ekor kuning dan berubahnya komposisi ikan yang ada di perairan telah mendorong nelayan untuk mengganti alat tangkapnya dengan alat tangkap yang lebih efisien untuk menangkap ekor kuning. Orientasi penangkapan ikan, seperti yang dijelaskan dalam Tabel 1, telah mengalami perubahan. Ikan hasil tangkapan dalam tiga tahun terakhir lebih dari 50\% didominasi oleh ikan kuning. Sebagai akibatnya, kesetimbangan ekosistem perikanan dan biomass ikan cenderung menurun (Ardiwijaya et al., 2008).

Bila ditinjau dari aspek ekonomi, hasil penelitian ini menunjukkan bahwa biaya operasi penangkapan ikan dengan menggunakan muroami jauh lebih besar dibandingkan dengan speargun. Perbandingan rasio pendapatan dan biaya menunjukkan bahwa alat tangkap speargun jauh lebih efisien dibandingkan dengan muroami. Biaya operasi penangkapan ikan yang jauh lebih rendah diduga menjadi pertimbangan nelayan dalam memilih speargun sebagai alat tangkapnya. Dengan biaya yang jauh lebih rendah sementara hasil tangkapan semakin menurun maka nelayan akan memilih suatu alat tangkap yang risiko kegagalan (kerugian) penangkapan ikannya kecil, sehingga speargun yang lebih efisien dan biaya penangkapan ikan yang rendah menjadi alternatif alat tangkap untuk menggantikan muroami. Hasil penelitian ini sesuai dengan pandangan Bene (1996), dikatakan bahwa salah satu penyebab perubahan strategi operasi penangkapan ikan nelayan adalah upaya memaksimalkan pendapatan. Keterbatasan sumberdaya modal untuk operasi penangkapan ikan, menjadi pertimbangan tersendiri bagi nelayan dalam mengembangkan pola adaptasi strategi operasi penangkapan ikannya. Mereka berusaha untuk memaksimumkan pendapatannya dalam keterbatasan modal usaha yang mereka miliki.
Berdasarkan temuan yang ada, dapat diketahui bahwa perikanan di Karimunjawa sangat dinamik, sementara upaya pengelolaannya belum optimal. Nelayan telah melakukan upaya dinamis untuk merspon perubahan lingkungan yang ada dengan melakukan perubahan alat penangkapan ikan. Kecenderungan-kecenderungan respon nelayan seperti ini sudah selayaknya diantisipasi oleh pengelola perikanan. Harapannya, arah perkembangan perikanan dapat diketahui dan kemudian akan mampu diterapkan mekanisme pengaturannya yang lebih tepat. Dalam kasus Karimunjawa, perikanan ekor kuning yang berkembang sangat cepat perlu diantisipasi dengan menghitung biomass ikan dan keterkaitannya dengan sumberdaya lainnya, sehingga diperoleh gambaran yang lengkap tentang rantai makanan dan jaring makanan yang terjadi. Selanjutnya, berdasarkan kondisi tersebut dan kecenderungan pola-pola adaptasi nelayan dalam operasi penangkapan ikan, dapat ditentukan pengelolaan perikanan yang lebih baik.

\section{KESIMPULAN DAN SARAN}

\subsection{Kesimpulan}

Berdasarkan hasil penelitian ini dapat disimpulkan bahwa:

1. Pengkajian dalam dua periode pengamatan (2003 - 2005 dan 2009 2011) terhadap upaya penangkapan ikan (trip), hasil tangkapan dan produktivitas per trip alat tangkap utama yang dioperasikan oleh nelayan Karimunjawa menunjukkan adanya perubahan yang signifikan. Alat tangkap muroami yang sebelumnya mendominasi trip dan hasil tangkapan, digantikan oleh alat tangkap speargun (panah) dan beberapa alat tangkap lain seperti bubu dan handline.

2. Dalam merespon perubahan permintaan pasar dan ekologi perairan (komposisi hasil tangkapan), nelayan Karimunjawa mengganti alat tangkapnya yang lebih efisien dan rendah biaya, yaitu speargun. 


\subsection{Saran}

Agar perkembangan alat tangkap yang digunakan oleh nelayan terkendali, maka sudah saatnya pemda atau lembaga yang diberi amanah menangani perikanan di Karimunjawa melakukan pengelolaan perikanan tidak saja dengan pendekatan biologi semata tetapi juga dengan pendekatan dinamika alat tangkap termasuk di dalamnya tentang pola adaptasi stratagi operasi penangkapan ikan oleh nelayan.

\section{DAFTAR PUSTAKA}

Ardiwijaya, R.L., T. Kartawijaya, F. Setiawan, Y. Herdiana. 2008. Laporan Teknis - Monitoring Ekologi Taman Nasional Karimunjawa 2007, Monitoring Fase 3. Wildlife Conservation Society - Marine Program Indonesia. Bogor, Indonesia.

Béné, C. 1996. Effect of market constrains, the remuneration system, and resources dynamics on the spatial distribution of fishing effort. Can. J. Fish. Aquat. Sci., 53, 563-571.

Berkes F., R. Mahon, P. McConney, R. Pollnac and R. Pomeroy. 2001. Managing Small-Scale Fisheries: Alternative Directions and Methods. IDRC, Ottawa. 320pp.

Campbell, S.J., and S.T. Pardede., 2006. Reef Fish Structure and Cascading Effect in Response to Artisanal Fishing Pressure. Fisheries Research 79 : 75-83.

Cesar, H., Lundin, C.G., Bentencourt, S., John, D. 1997. Indonesian Coral Reefs-an Economic Analysis of a Precious but Threatened Resource. Ambio 26, 345-350.

Cinner, J. E., and T. R. McClanahan. 2006. Socioeconomic Factors That Lead to Overfishing in Small-scale Coral Reef Fisheries of Papua New Guinea. Environmental Conservation 33 : 1-8.
Cinner, J. E., T. Daw and T.R. McClanahan. 2008.

Socioeconomic Factors that Affect Artisanal Fishers' Readiness to Exit a Declining Fishery. Conservation Biology. 23 :124130.

Hazin, HG, Hazin F, Travassos P, Carvalho FC, and Erzini, K. 2007. Fishing strategy and target species of the Brazilian Tuna Longline fishery, from 1978 to 2005, inferred from cluster analysis. Col. Vol. Sci. Pap. ICCAT, 60(6): 2029-2038.

McClanahan, T.R and Mangi, S. 2000. Spillover of Exploitable Fishes from a Marine Park and It's Effect on the Adjacent Fishery. Ecological Applications 10: 17921805.

Mukminin, A., T. Kartawijaya, Y. Herdiana, I. Yulianto. 2006. Laporan Monitoring. Kajian Pola Pemanfaatan Perikanan di Karimunjawa (2003-2005). Wildlife Conservation Society Marine Program Indonesia. Bogor, Indonesia. 35pp.

Ricker, W.E. 1975. Computation and interpretation of biological statistics of fish population. Bull. Fish. Res. Bd Can. 191, 1-382.

Salas, S., and D. Gaertner (2004): The behavioral dynamics of fishers: management implications. Fish Fish., 5, 153-167.

Wibowo, J.T. 2005. Aspek Sosial Ekonomi dalam Pengelolaan Tamana Nasional Karimunjawa. Laporan Monitoring. Wildlife Conservation Society - Indonesia Marine Program. Bogor. 